\title{
Prime Minister Modi Returns, 2019: New Governance Agenda
}

Dr Rituparna Bhattacharyya ${ }^{+*}$ and Dr Venkat Pulla ${ }^{\dagger}$

\section{Abstract}

This editorial reviews the historic mandate of India's General Election of 2019, preceding nasty campaigns and futurist agenda for Mr Modi's second term.

Keywords: General Election 2019; Good Governance; India

\footnotetext{
${ }^{+}$Editor-in Chief (joint), Journal Space and Culture, India

* Corresponding Author, Email: rituparna.bhattacharyya@accb.org.uk

(C) 2019 Bhattacharyya and Pulla. This is an Open Access article distributed under the terms of the Creative Commons Attribution License (http://creativecommons.org/licenses/by/2.0), which permits unrestricted use, distribution, and reproduction in any medium, provided the original work is properly cited.
} 


\section{Introduction}

Elections have their place in [a] democracy, and it is the responsibility of the winner to take care of 130 crore people. Those who made us win or those who did not both are our (people). Kerala is as dear to me as Varanasi is ${ }^{1}$

After a historic mandate of 23 May 2019 in the 17th Indian General (Lok Sabha) Election, the Prime Minister of India, Mr Narendra Damodar Das Modi, visited Kerala to attend an Abhinandan Sabha ${ }^{2}$ on 08 June 2019 organised by the Kerala unit of his party Bharatiya Janata Party (BJP), in Guruvayur where he made the above statement. Although the BJP has failed to

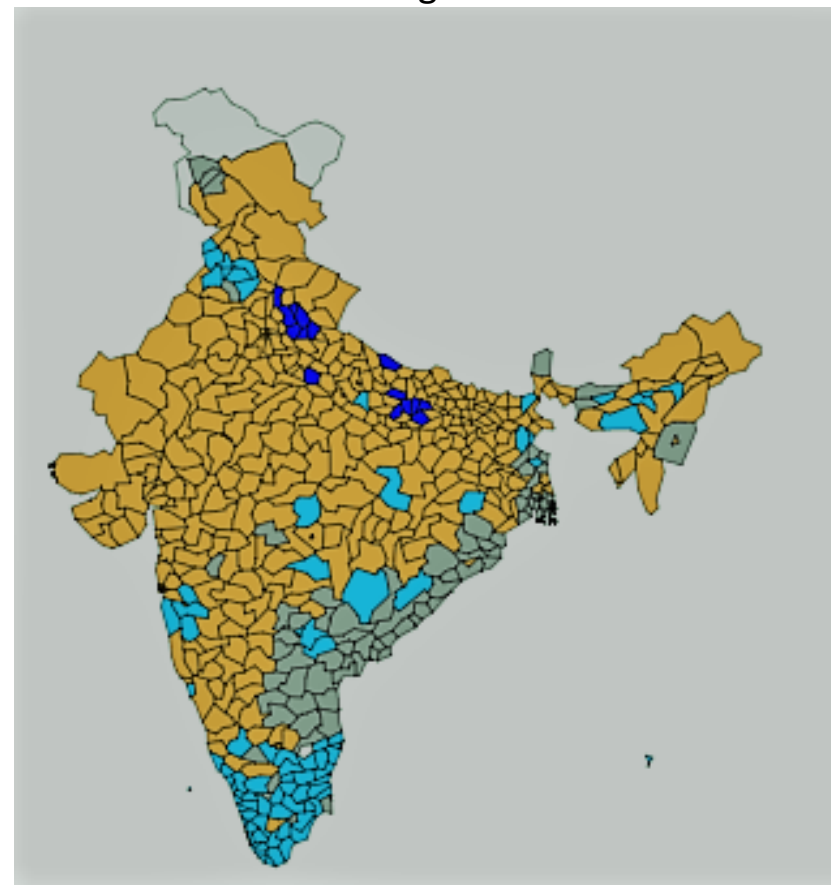

win any seats in Kerala, the National Democratic Alliance (NDA) swept the General Election 2019, winning 343 constituencies out of $542 .^{3}$ This is a clear win for Modi, personally and for his government. The BJP alone accomplished 303 constituencies as opposed to 52 by the Indian National Congress; ${ }^{4}$ albeit the United Progressive Alliance (UPA) obtained 90 seats while the other 99 constituencies have been shared by so-called Mahagathbandhan (MGBan alliance of Bahujan Samaj Party and Samaj Badi Party, known as BSP+, who managed only 15 constituencies) and others -84 . The detailed breakdown of the seat share is illustrated in Figure 1.

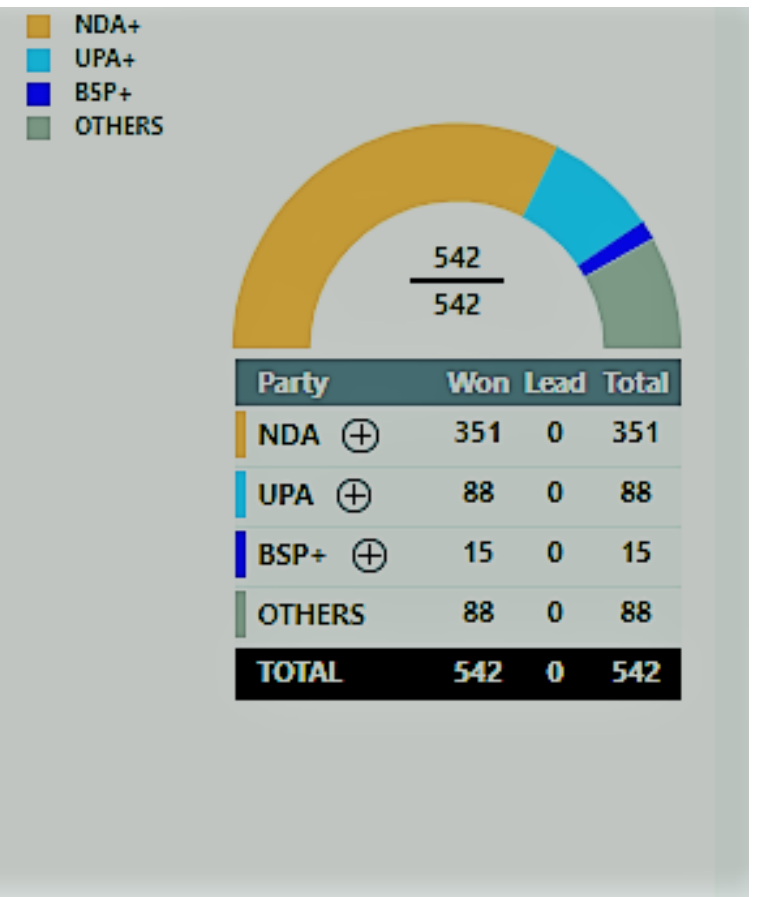

Figure 1: Lok Sabha Results 2019, The Hindu. Retrieved on 02 June 2019 from, https://www.thehindu.com/elections/lok-sabha-2019/

The 2019 election was grappled by some of the ugliest forms of campaign mediated through a constant stream of abuses showered upon a sitting Prime Minister, by the opposition and political elites. The opposition relentlessly hurled 'real lies' at PM Modi by continuously chanting Chowkidar Chor Hai (the gatekeeper is a thief), alleging nepotism in awarding contracts and escalating the price of Dassault Rafale fighter jet deal. The BJP cadres invigorated this

\footnotetext{
1 People are God in elections: Narendra Modi (2019, 08 June).The Daily Star. Retrieved 08 June 2019 from, https://www.thedailystar.net/india/news/people-are-god-elections-narendra-modi-1754020

${ }^{2}$ Abhinandan means congratulations and Sabha means assembly

${ }^{3}$ There are 543 consitutuencies but in one (Vellore), election was cancelled by the Election Commission.

${ }^{4}$ General Election to Lok Sabha Trends \& Result 2019, Election Commission of India. Retrieved 08 June 2019 from, http://results.eci.gov.in/pc/en/partywise/index.htm
} 
name calling into a positive tagline by changing their social media handles as Main Bhi Chowkidar (I am also a gatekeeper).

Rash utterances, signature campaigns and slimy hatred, mime wars, arson, violence and killings have marred the elections. The Chief Minister of West Bengal, Mamta Banerjee, a very bitter lady, went to the extent of calling PM Modi and Mr Amit Shah as goondas (Das,2019)..$^{5}$ A group of about 600 theatre personalities and intellectuals signed a petition requesting the citizens of India to vote the incumbent government out of power urging the electorate to cast for "equality and social justice, and to defeat the forces of darkness and barbarism" (Dixit, 2019). Another group of 907 artists countered this petition and issued a joint letter entitled: Nation First Collective: an initiative by Creative Collective Trust pleading the voters to re-elect the NDA-led government (Sharma, 2019). The signatories stated:

We, creative artists and persons belonging to the field of literature appeal to all our fellow citizens to cast their vote and exercise their right to elect the new Govt. without any pressure and prejudice.

We believe that during the last five years, India has seen a Govt. that has delivered corruption-free good governance and development-oriented administration. During this period, globally, India has acquired greater respect. It is our firm conviction that the continuance of Govt. led by Prime Minister Narendra Modi is the need of the hour.

Besides, when challenges like terrorism are before all of us, we need a "Majboot Sarkar" and not a "Mazboor Sarkar", and hence we need the present Govt. to continue (Dixit, 2019).

However, a day after the election results (that is, on 24 May 2019), in an article entitled Modi won power, not battle of ideas published in The New York Times, Amartya Sen was critical of the

\footnotetext{
${ }^{5}$ a hired individual to commit a crime or cause damage
}

performance of the first five years of the Modi government. He was also critical of the election of Ms Pragya Thakur from Bhopal, who was charged with the 2008 Malegaon blasts (Sen, 2019). Ideally, no accused should ever get into an avatar of a lawmaker.

There has been fierce criticism that a person with 'Hindu-terror' charges has won against a two-term former Chief Minister, Member of Parliament and a very influential person of the Congress, Mr Digvijaya Singh. Traditionally, Bhopal constituency has been a strong BJP bastion since 1989 with approximately 69 per cent of the population following the Hindu religion. Nuanced observation unveils that the opposition themselves are responsible for the win of Pragya Thakur by associating a heinous crime like 'terror' with Hindu religion, thereby fueling the emotional sentiments of the electorates of Bhopal. Indeed, to avoid antiincumbency but taking into consideration the winnability factors (such as class, caste and community), the BJP strategically steered a smart and a prudent move across the country in issuing tickets to the candidates. As a consequence, many sitting MPs were refused tickets. For example, Mr Kamakhya Prasad Tasa, who is a representative of the tea tribes and had won the 2014 General Election from Jorhat constituency, Assam was denied a ticket. Instead, the BJP fielded Mr Topon Kumar Gogoi, who hails from the Ahom community to contest against Mr Sushanta Borgohain of the INC, who also belong to the Ahom community. These pedantic strategies not only helped the BJP to an emphatic sweep but also increased the vote share from 31.1 per cent in 2014 to 37.4 per cent in 2019 (Election Commission of India). Interestingly, the vote share of the BJP in about 13 states (Uttar Pradesh, Haryana, Madhya Pradesh, Rajasthan, Chhattisgarh, Uttarakhand, Gujarat, Jharkhand, Himachal Pradesh, Goa, Karnataka, Delhi, Chandigarh and Arunachal Pradesh) was either equivalent or more than 50 per cent (Election Commission of India).

However, Pragya Thakur is not the only accused who was given a ticket; indeed, as per 
Association of Democratic Reforms, nearly 43 facing criminal charges are continuously on the per cent, out of 539 winning candidates are rise since 2004. Figures 2 and 3 illustrate this. accused of some form of criminal charges including some of the heinous forms like rape and murder. Sadly, the number of candidates

\section{Figure 2: Percentage of Lok Sabha MPs with Criminal Charges, 2019 \\ Source: Association of Democratic Reforms}

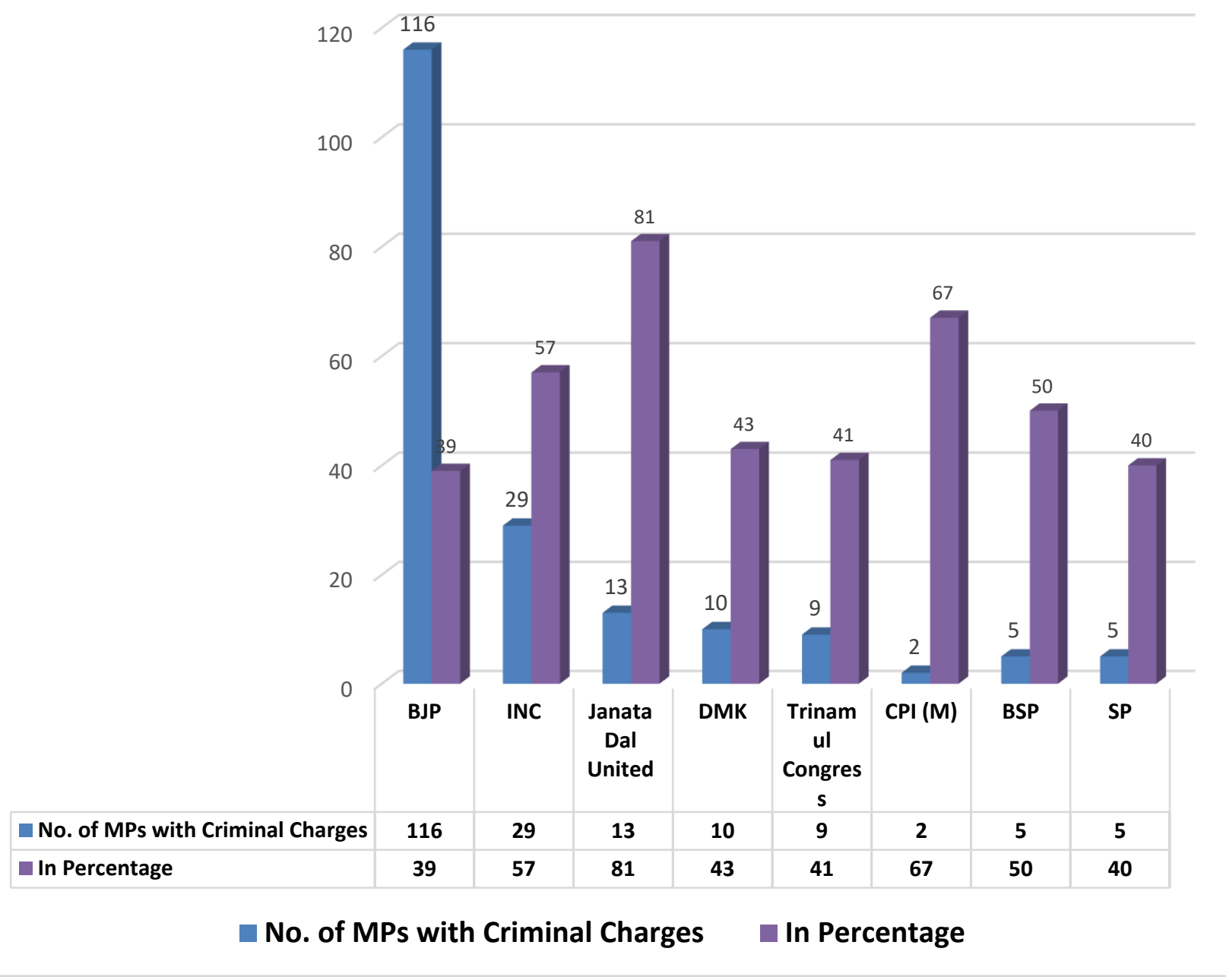




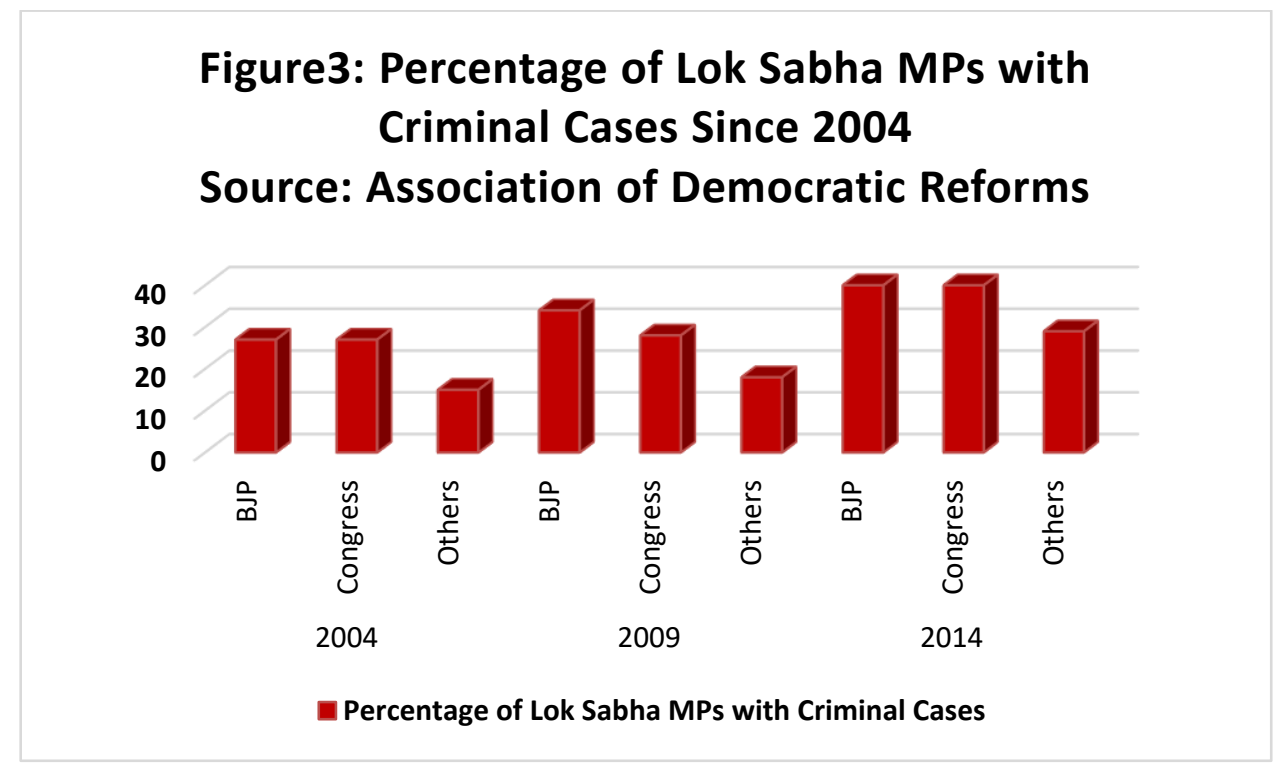

Arguably, Mr Modi's leadership, himself hailing from a humble background, chai wallah (tea seller) fits into the notion of 'counter-hegemony' (Pulla, 2017) as put forward by Antonio Gramsci (1999). According to Gramsci there are two faces of the notion hegemony:

On the one hand it is contrasted with "domination" (and as such bound up with the opposition State/Civil Society) and on the other hand "hegemonic" is sometimes used as an opposite of "corporate" or "economic-corporate" to designate an historical phase in which a given group moves beyond a position of corporate existence and defence of its economic position and aspires to a position of leadership in the political and social arena (Gramsci, 1999: 20).

Mr Modi, who is considered as "the messiah (the saviour) of the poor" (Pulla, 2017: 4) has definitely "added swaabhimaan (self-respect) to [ the] tenacity and elevated [the] hopes" (Pulla, 2017:1) of the poor. And the 2019 Election has been about the 'hopes' and 'aspirations' of the masses irrespective of class, caste, creed and religion and their fundamental rights to live in dignity. In a similar context, Singh (2019) argues that during the leadership of Modi since 2014 , the importance of privilege class has witnessed a steady decline. She goes on to argue:
The past five years have been difficult for India's ruling elite. High officials, famous writers, editors of English newspapers, celebrated TV anchors, heirs of political dynasties, leftists and liberals have found their importance diminish by the day. They have been replaced by people they once dismissed as 'vernacs', the word they use derisively for Indians who speak only in the vernacular. If 'liberal' journalists are astoundingly illiberal in their assessments of Modi it is because they have suffered badly since there was regime change in 2014. Where they once had privileged access to the men and women who rule India, they are now relegated to unseen TV channels while Hindi journalists get all the interviews and all the glory.

Nonetheless, prior to the election results of 23 May, Aatish Tasir (2019, 09 May), in his article titled Can the World's Largest Democracy Endure Another Five Years of a Modi Government? published in Time Magazine, vehemently criticised PM Modi, labelling him as the 'Divider in Chief', which, however, endured fierce criticism. The same issue went on to publish another article on PM Modi by lan Bremmer (2019, 09 May) critically analysing both the success and failures of the Modi government. Similar criticisms were also published by other renowned magazines like The Economist- 
Narendra Modi and the struggle for India's soul (2019, 02 March); ${ }^{6}$ Missiles maketh the man: Nationalist fervour is likely to secure a second term for Narendra Modi (2019, 04 May). ${ }^{7}$ However, with the change of time- post-23 May, the tone of these magazines too have changed. For instance, while the Time published an article entitled Modi Has United India Like No Prime Minister in Decades by Manoj Ladwa (2019, 28 May); similarly, The Economist published articles mostly carrying metaphors linked to adulations - India's election results: Narendra Modi scores a remarkable election victory; ${ }^{8}$ Hindu juggernaut: What Narendra Modi should do next (2019, 25 May). ${ }^{9}$

The key questions are, despite the indignant forms of abuses and criticisms against PM Modi and the NDA as a whole, why did the electorates manage to score a spectacular victory for the NDA and re-electing it for a second term - is it that the electorates have rejected the largest opposition party, the Indian National Congress and its PM face, Mr Rahul Gandhi?; or is it that PM Modi has been successful in reaffirming confidence amongst the electorates through some form of 'good governance' since 2014 visà-vis connection with the mass with its various flagship programmes/schemes, virtual connection through Mann Ki Baat (Heart's Voice) aired through All India Radio and Doordarshan; and revocation of some archaic statutes and amendment of some of the old legislation? Perhaps, the answer resides in the mixed bag of both.

Cascaded by the slogan-Sab Ka Saath, Sab Ka Vikas (Collective Efforts, Inclusive Growth), the 2014 NaMo (Narendra Modi) wave emerged on the 'Gujarat Model of Development', which was played out as a synonym of Modinomics (for details, please see, Bhattacharyya, 2014) stemming from BJP's ideology of multidimensional progress and its inclusive vigour of

\footnotetext{
${ }^{6}$ Retrieved on 03March 2019 from,

https://www.economist.com/briefing/2019/03/02/naren dra-modi-and-the-struggle-for-indias-soul

${ }^{7}$ Retrieved on 05May 2019 from,

https://www.economist.com/asia/2019/05/04/nationalis t-fervour-is-likely-to-secure-a-second-term-for-narendramodi
}

nation-building. Post-2014, the new NDA Government of India undertook three forms of social and economic reforms-immediate, medium and long term and launched a number of new initiatives - Make in India (25 September 2014), Clean India or Swachh Bharat Abhiyan (02 October 2014) and Saansad Adarsh Gram Yojana (MP Model Village Scheme, on 11 October 2014, PM himself adopted the Jayapur village, $35 \mathrm{~km}$ from Varanasi). Through these initiatives, the Government of India articulates its vision to transform India into a social and economic hub. Driving these 'pluralistic' initiatives, Mr Modi aims to reach the remotest corners of the country and integrate the 'strength' of the nation in its 'inclusive development'journey (Bhattacharyya, 2017) to accomplish the first Deputy Prime Minister of India, Sardar Vallabhbhai Patel's (31 October 1875-15 December 1950) vision of 'Ek Bharat, Shreshtha Bharat' and build a New India by 2022.

For instances, Make in India "aims to build India a manufacturing hub under the mission Manufacture in India and sell the products worldwide. Central to Make in India campaign is 'skill development' and 'creation of jobs' through the mobilisation of the "youth power" (Bhattacharyya, 2017: 1). Although it is unclear as to what extent his mission has been able to develop the skills of the youths and create jobs; but a job survey- Periodic Labour Force Survey (PLFS) for 2017-18 by the National Sample Survey Office's (NSSO) unravelled that unemployment rate is staggeringly high in 45 years, which stood at 6.1 per cent (rural areas: 5.3 per cent and urban areas: 7.8 per cent) and the participation of females in the labour market of urban areas at "the quarter ending December 2018 was $19.5 \%$, compared with $73.6 \%$ for

\footnotetext{
${ }^{8}$ Retrieved on 26 May 2019 from, https://www.economist.com/asia/2019/05/23/narendramodi-scores-a-remarkable-election-victory

${ }^{9}$ Retrieved on 26 May 2019 from, https://www.economist.com/leaders/2019/05/25/whatnarendra-modi-should-do-next
} 
males". ${ }^{10}$ Nonetheless, there is evidence to suggest that Make in India has improved the ease of doing business in India. According to the latest World Bank Flagship report-Doing Business 2019: Training for Reform, India and China, the two emerging economies are amongst the top ten improvers of boosting business regulations. $^{11}$ Scoring 67.23 points, an improvement of +6.63 , India ranks 77 (out of 190 economies) in the ease of doing business. In 2018, its rank was 100, which was a jump of 30 ranks from 2017. The indicators where the country improved its rank in 2019 from the previous year are- construction permits from 181rank to the 52nd position; trading across the borders from 146 positions to 80th rank; from 156th to 137th position in starting a business; there has been an improvement of seven points in getting credit (from 29th to 22nd position); similarly, there has been an improvement of five points in acquiring electricity (from 29 to 24th rank); and a meagre increase of enforcing contracts by one point (that is from 164th to 163rd position). ${ }^{12}$

Similarly, under Clean India or Swachh Bharat Abhiyan, which operates mainly under two ministries- Ministry of Drinking Water and Sanitation (primarily) for rural areas; and Swachh Bharat Abhiyan (urban) gained massive success in building toilets especially in the rural areas. As of 2014, nearly 600 million Indians used to defecate in open spaces (Bhattacharyya, 2014); the percentage of households having toilets stood approximately at 38.70. Post-2014 (02 October), 96190760 household toilets have

\footnotetext{
10 Unemployment rate rises to 45 -year high of $6.1 \%$ in FY18: Official data (2019, 31 May), Live Mint. Retrieved on 14 June 2019 from,

https://www.livemint.com/news/india/unemploymentrate-rises-to-45-year-high-of-6-1-in-fy18-official-data1559306879836.html and Cat finally out of the bag: Unemployment at 45-year high, government defends data (2019, 31 May). India Today. Retrieved on 14 June 2019 from,

https://www.indiatoday.in/business/story/indiaunemployment-rate-6-1-per-cent-45-year-high-nssoreport-1539580-2019-05-31

${ }^{11}$ Doing Business 2019: Training for Reform, A World Bank Group Flagship Report, Retrieved on 14 June 2019 from,

http://www.doingbusiness.org/content/dam/doingBusin
}

been built. Statistics claim that 564658 villages have been made open defecation free and 618 are open defecation free districts. ${ }^{13}$ However, it is not easy to change the behaviour of the people who are habituated to defecating in the open and considers that having a toilet at home is an impure practice (Frøystad, 2018; Lakshmi, 2015; Nathoo, 2015; Ramani, 2016). Toilet: Ek Prem Katha (Toilet: A Love Story), the 2017 Bollywood film, directed by Shree Narayan Singh and coproduced by the Bollywood actor, Mr Akshay Kumar (who played the lead role) and Neeraj Pandey demonstrates the attitudes of the people succinctly in using toilets within their premises (Frøystad, 2018). Hence, simultaneous awareness building remains paramount for the successful execution of this mission.

As stated elsewhere, in its mission of 'social inclusiveness', the government has either revoked old legislation or taken initiatives to promulgate new ones. For example, declaring 'talaq' a cognisable offence, on 12 January 2019, the Government promulgated the Muslim Women (Protection of Rights on Marriage) Ordinance, 2019. However, following the dissolution of the 16th Lok Sabha, the government had failed to pass the Muslim Women (Protection of Rights on Marriage) Bill, 2018 (please read Sur, 2018 for a detailed understanding of the bill) in the Rajya Sabha, which was already passed by Lok Sabha on 27 December 2018. Nevertheless, on 21 June 2019, the newly elected government has again freshly introduced The Muslim Women (Protection of Rights on Marriage) Bill 2019. ${ }^{14}$ Similarly, the

ess/media/Annual-Reports/English/DB2019-report_webversion.pdf

${ }^{12} 5$ Highlights from World Bank's Doing Business 2019 report, Make in India. Retrieved 10 June 2019 from, http://www.makeinindia.com/five-highlights-from-worldbanks-doing-business-report-

2019?utm_source=homepage\&utm_medium=homepage ${ }^{13}$ Swachh Bharat Mission (Gramin). Retrieved on 14 June 2019 from,

http://sbm.gov.in/sbmdashboard/Default.aspx\#

${ }^{14}$ Fresh triple talaq bill introduced in Lok Sabha $(2019,21$

June).The Hindu Business Line. Retrieved on 22 June 2019 from,

https://www.thehindubusinessline.com/news/freshtriple-talaq-bill-introduced-in-lok-

sabha/article28097516.ece 
government has taken other significant steps to empower working women, the marginalised and the victims - be it, amendment of the Maternity Act from earlier 12 weeks to 26 weeks, provisions of work from home option, crèche facilities (please read, Singh, 2016); amendment of the Protection of Children from Sexual Offences (POCSO) Act by awarding death penalty for the rape of minors below 12 years old (Singh, 2018); amendment of the Juvenile Justice Act ,2015 (Agarwal and Kumar, 2016) the need of which became paramount in the wake of the gang-rape of the 23-year-old Nirbhaya by six men in December 2012 (Bhattacharyya, 2015a; 2016), where one of the perpetrators was a juvenile. Further, on 6 September 2018, the historic judgment passed by the Honourable Apex Court by decriminalising Article $377,{ }^{15}$ thereby legitimising consensual sexual acts amongst adults of the same sex (Kakoti Borah, 2018) obviously added indirect advantage to Modi's report card on 'good governance'. There is no doubt that the BJP was able to transcend the class/caste/religion divide-the results of Uttar Pradesh and Bihar, which previously used to garner votes through appeasement of caste and religion are evidence to this.

Two other radical moves taken by the Modi government has been implementation of Goods and Service Taxes (GST) aimed at streamlining the complex system of revenue collection (for a detailed understanding of this topic, please read Mahanta, 2016) and Demonetisation, through which the old currency notes of ₹500 and ₹1000 were withdrawn and replaced by new notes of $₹ 500$ and $₹ 2000$ (Pulla, 2016). Pegged at multiple rates, $0 \%, 5 \%, 12 \%, 18 \%$ and $28 \%$, and barring few goods- petroleum products, alcoholic drinks, real estate and electricity, the GST, which came into effect from 01 July 2017 witnessed a revenue collection of ₹900 billion for the period July 2017-March 2018, which further surged to

\footnotetext{
${ }^{15}$ Article 377 of the Indian Penal Code was indeed a colonial piece of legislation introduced in 1864 during the British regime making homo sexual activities as illegal (Rajagopal, 2018).

${ }^{16}$ Digital Payments: India, Statista . Retrieved on 21 June 2019 from,
}

₹1138.65 billion in April 2019, of which ₹ 211.63 billion is Central GST. The figure for State GST stood at ₹288.01 billion, while Integrated GST for April 2019 stood at ₹547.33 billion. Demonetisation, which aimed mainly at tackling black money, corruption and terrorism (Pulla, 2016), of course, had a robust but short term impact on the cash economy, the unorganised sector and micro, small and medium businesses. Although, it remains unclear as to whether the government could accomplish its demonetisation goals; that none of the political parties had 'curbing corruption' in their election manifestos demonstrates that because of the tightening of regulations in the government institutions, the pace of corruption has been slowly declining.

Nonetheless, the currency circulation, which was ₹17.78 trillion at the time of demonetisation drive in November 2016, has increased to ₹21.37 trillion in April 2019 (Alexander and Padmanabhan, 2019a). Besides, the cash-GDP ratio too is slightly lower when compared to the pre-demonetisation level- this ratio was 12.1 in 2015-2016, plummeted to 8.7 in 2016-2017 but surged to 11.2 in 2018-19 (Alexander and Padmanabhan, 2019a). However, one has to acknowledge that demonetisation has improved the cashless mode of the transaction (Bhattacharyya, 2017) - in 2019, the country's cashless transaction stood at the US $\$ 64,787$ million, which is obviously one of the roads to financial inclusion. ${ }^{16}$ A 2018 report titled World Payments Report published by Capgemini also reveals that the country's cashless transaction, which has grown at 33.2 per cent stands second to Russia (36.5 per cent); China's cashless growth stands at 25.8 per cent, while South Africa's growth is at 15.1 per cent. ${ }^{17}$ In the interim budget, 2019-2020, the then Minister of Finance, Mr Piyush Goyel, in his Budget Speech mentioned that "[i]n order to

https://www.statista.com/outlook/296/119/digitalpayments/india

${ }^{17}$ World Payments Report (2018). Capgemini. Retrieved on 21 June 2019 from, https://worldpaymentsreport.com/wpcontent/uploads/sites/5/2018/10/World-PaymentsReport-2018.pdf 
promote a less cash economy, the presumptive profit rate has been reduced from $8 \%$ to $6 \%$ " (page 14). ${ }^{18}$ The upcoming Budget should definitely levy lower tax rates to promote higher cashless transaction.

Before the demonetisation drive, another important flagship initiative launched by the Government was Pradhan Mantri Jan Dhan Yojna - a scheme of financial inclusion of the poor (Singareddy et al., 2019). Launched under the Slogan-Mera Khatha, Bhagya Vidhatha (My Account would beget a good fortune) in August 2014, the scheme has made to the Guinness Book of World Records which stated: "[t]he most bank accounts opened in one week as a part of the financial inclusion campaign is $18,096,130$ and was achieved by the Government of India from August 23 to 29, 2014". ${ }^{19}$ As per available statistics, over 318 million bank accounts were opened under this scheme, which had a deposit of ₹792 billion (US\$12 billion) (Singareddy et al., 2019). Although, there has been criticism that the majority of these bank accounts have remained inactive since its opening, however, the latest report published in The Hindu, Business Line (2019) unveils that:

There has been a rise of up to 24 per cent in the average balance of these accounts across banks during the last one year, according to individual data available with major banks. Banks claim the surge is the highest so far.

State Bank of India (SBI) witnessed an increase of more than 24 per cent in the average balance of financial inclusion accounts to ₹1,988 in December 2018, against ₹1,594 in the year-ago period.

For Bank of Baroda, the same had gone up from ₹2,875 to ₹3,169, while Punjab National Bank registered an increase

\footnotetext{
18 Interim Budget 2019-2020, Speech of Piyush Goyal Minister of Finance February 1, 2019, Union Budget. Retrieved on 20 June 2019 from, https://www.indiabudget.gov.in/budget/budgetspeech.p $\mathrm{hp}$
}

from ₹1,879 in December 2017 to ₹2,217 in December 2018 (Sridhar, 2019)

The report goes on to divulge that the percentage of zero balance accounts have reduced and currently stands in between 17-19 per cent (Sridhar, 2019). One has to acknowledge that having an account even with zero balance is a strength in itself-a form of formal financial inclusion, which would ease an individual's woes when applying for loans for business or to become a beneficiary of a government/non-government programme including direct cash transfer. The implementation of Aadhar cards, a unique identity allowing biometric authentication, assigned to 1.24 billion people have only further strengthened the spine of the economy by reducing leakages and validating welfare delivery to the actual beneficiary(Padmanabhan, 2019). However, one has to confess that the concept of Aadhar was first propounded by the UPA (Padmanabhan, 2019).

Alongside, the hits and misses of the schemes of the NDA government, it is not to argue that the government under the UPA had a very poor economic scorecard. The comparison of some of the performance and slugfest of both the UPA and NDA are encapsulated in Table 1.

It is apparent from Table 1 that the scale of the performance of the five years of the NDA government has been better than the UPA that governed the country since 2004. In terms of rural electrification, it was indeed the UPA government that had completed nearly 97 per cent (with 80,189 villages being electrified) under its regime. The NDA government, however, has extended this scheme under Sahaj Bijli Har Ghar Yojana (Saubhagya). Leisang in Manipur is one of the latest villages to have been electrified. According to Saubhagya, 21,44,73,043 (99.99 per cent) households have been electrified, and only 18,734 (0.01 per cent)

19 Jan Dhan Yojana features in Guinness Book of World Records with $11.5 \mathrm{cr}$ bank accounts (2015, 21 January. The Indian Express. Retrieved on 21 June 2019 from, https://indianexpress.com/article/business/businessothers/jan-dhan-yojana-enters-into-guinness-bookrecord-with-1-5-cr-accounts/ 
households remain to be connected with (2019b). It is saddening to witness that even the electricity. ${ }^{20}$ Evidently, the quality of these urban areas and metropolitan cities suffer from connectivities has been extremely poor with no the $24 X 7$ regular supply, steered by high regular supply (Alexander and Padmanabhan fluctuations and load shedding.

\begin{tabular}{|c|c|c|}
\hline Indicators & UPA (2009-10 to 2013-14) & NDA (2014-15 to 2018-19) \\
\hline Average GDP growth & 6.7 & 7.5 \\
\hline Agriculture GDP growth (in \%) & 4 & 2.4 \\
\hline Value Added in Agriculture & 4.3 & 2.9 \\
\hline Industry GDP Growth (in \%) & 6.4 & 7.1 \\
\hline Value Added in Manufacturing & 6.4 & 8.6 \\
\hline Services GDP growth (in \%) & 8.3 & 8.8 \\
\hline Consumer Price Index Inflation & 10.3 & 4.8 \\
\hline Fiscal Deficit to GDP & 5.35 & 6.35 \\
\hline $\begin{array}{l}\text { The Index of Industrial } \\
\text { Production growth }\end{array}$ & 4.6 & 4.17 \\
\hline Exports Growth & 12.6 & 1.5 \\
\hline Non-Performing Asset (pt-to-pt) & 2.25 to 3.84 & 3.84 to 10.4 (December, 2018) \\
\hline Gross Fixed Capital Formation & 33.24 & 28.9 \\
\hline Sensex (pt-to-pt) & 9,768 to $22,386(130 \%)$ & 22,386 to $38,673(73 \%)$ \\
\hline Current Account Deficit & -3.34 & -1.43 \\
\hline $\begin{array}{l}\text { Forex Reserves (\$\$billion) (pt-to- } \\
\text { pt) }\end{array}$ & 264.1 to 303.6 & 303.6 to 411.9 \\
\hline FDI (\$̧billion) Cumulative & 179.7 & 268.5 \\
\hline FDI Inflow (\$̦billion) & 38.4 & 52.2 \\
\hline Bad Loans & 1230 billion & 6620 billion \\
\hline Gross Tax Revenue & 8360 billion & 15900 billion \\
\hline Income Tax Returns Filed & $38000000(2014)$ & $69000000(2018)$ \\
\hline Adults with Bank Account (in \%) & $53(2014)$ & $80(2018)$ \\
\hline Highways (in kms) built per year & 4885 & 7750 \\
\hline Agricultural Insurance & 3000000 hectares (2013) & 58 million hectares (2017) \\
\hline Houses built each year & 2400000 & 2800000 \\
\hline Soil Health Cards (issued) & $28000000(2011-2014)$ & $92000000(2015-2017)$ \\
\hline Total Optical Fiber laid (in kms) & $5378(2009-2014)$ & $223,200(2014-2018)$ \\
\hline Rural Electrification & 80,189 villages & 52,611 villages \\
\hline
\end{tabular}

Under Ujjwala yojana, there has been a record from five out of 10 homes in 2014 (Choudhary, surge in Liquefied Petroleum Gas (LPG) 2018). According to the official website, 7, 23, connection to the poor households free of cost 25, 948 LPG connections have been made signalling that this form of cleaner fuel energy covering 714 districts. ${ }^{21}$ Table 2 illustrates a now connects nine out of 10 homes. This is a leap detailed picture of the LPG connection. It is

\footnotetext{
${ }^{20}$ Sahaj Bijli Har Ghar Yojana (Saubhagya). Retrieved on 20 June 2019 from, https://saubhagya.gov.in/
}

${ }^{21}$ Pradhan Mantri Ujjwala, Ministry of Pertroleum and Natural Gas. Retreved on 23 June 2019 from, http://www.pmujjwalayojana.com/. 
worth noting here that according to the Census of India (2011), while 72,435,303 households used kerosene as their key source of lighting, 897,760 households lived in darkness with no lighting facilities (Bhattacharyya,2015b). Despite the free LPG connection, the government continues to face challenges. This is simply because "LPG cylinders, even after subsidies, can be prohibitively costly for the poor. In addition, many households may simply be unaware about LPG's benefits; others may not know where to get a cylinder" (Alexander and Padmanabhan, 2019c).

Table 2: Connection of Liquefied Petroleum Gas (LPG) Cylinder

\begin{tabular}{|l|l|}
\hline Total Number of LPG (Domestic Connections) & 0.249 billion \\
\hline Number of Subsidised Connections & 0.229 billion \\
\hline Number of Double Cylinder Connections & 0.119 billion \\
\hline Number of Rural Connections & 0.113 billion \\
\hline Number of Urban Connections & 0.136 billion \\
\hline Number of Commercial Connections & 2900000 \\
\hline
\end{tabular}

Source: Choudhary (2018)

Another newly launched health scheme that has been gaining ground is the Ayushman Bharat Yojana, which was launched on 23 September 2018. Already 29,16,040 beneficiaries have been admitted in over 15,623 empanelled hospitals ${ }^{22}$ ensuring payments of an insurance cover of ₹ 5000 00per annum to 0.5 billion people. This flagship initiative has been applauded by the Director General of the World Health Organisation, Tedros Ghebreyesus. ${ }^{23}$ The scheme is still at its embryonic form and only time will testify as to what extent this scheme gains success.

All these competing narratives, despite its own successes and failures, demonstrates that the seeds of development have been planted. These narratives further signal that there is a sheer political will of the government to transform the country for better.

Himself taking a holy dip at Kumbh Mela, PM Modi paid tributes to the Safai Karamcharis(sanitation workers) by washing the feet of five workers on 24 February 2019.

\footnotetext{
${ }^{22}$ National Health Authority. Government of India. Retrieved on 23 June 2019 from, https://www.pmjay.gov.in/

${ }^{23}$ WHO DG 'impressed' with Ayushman Bharat scheme; says it's a 'great commitment (2018, 07 September). The Economic Times. Retrieved on 23 June 2019 from, https://economictimes.indiatimes.com/industry/healthca re/biotech/healthcare/who-dg-impressed-with-
}

Although, metaphorically, this act was visual, but it won the hearts of the millions.

In addition, the organic and charismatic leadership of Modi was strengthened by the 2019 Balakot Airstrike, when on 26 February the Air Force "sent its package of 12 Mirage 2000 fighter aircraft to attack the Jaish-e-Mohammed terrorist camp", ${ }^{24}$ which is the first ever since the India-Pakistan war of 1971 that crossed the Line of Control.

\section{Future Expectations: Journey for a New India}

The 2019 Election mandate was undoubtedly a mandate bestowed by the poor for 'good governance'. The country's poor, who make up the majority of the population clearly realised the three positive Ns (Niyat-intention, Niti-policy and Neta-Leader). In the next five years, the country should seek to accomplish the ladder of a 'developed' nation through PM Modi's inclusive slogan of NARA (National Ambition, Regional Aspiration). Alongside other forms of development agendas, the flagship

ayushman-bharat-scheme-says-its-a-greatcommitment/articleshow/65720426.cms?from=mdr 24 'Operation Bandar' was IAF's code name for Balakot airstrike(2019, 21 June). The Economic Times. Retrieved on 23 June 2019 from,

https://economictimes.indiatimes.com/articleshow/6988 9631.cms?utm_source=contentofinterest\&utm_medium =text\&utm_campaign=cppst 
programmes, the government should take initiatives for the implementation of a uniform civil code plus put an end to the ongoing Kashmir issue.

\section{References}

Agarwal, S., \& Kumar, N. (2016). Juvenile Justice (Care and Protection of Children) Act 2015: A Review. Journal Space and Culture, India, 3(3), 5-9. https://doi.org/10.20896/saci.v3i3.165

Alexander, Sneha and Padmanabhan, Vishnu (2019a, 05 May). Despite hype, demonetization missed all goals. Live Mint. Retrieved on 20 June 2019 from, https://www.livemint.com/news/india/despitehype-demonetization-missed-all-goals1557059532885.html

Alexander, Sneha and Padmanabhan, Vishnu (2019b, 11 March). The curious case of electrification in India amid discom blackouts.Live Mint. Retrieved on 20 June 2019 from, https://www.livemint.com/elections/loksabha-elections/the-curious-case-ofelectrification-in-india-amid-power-discomblackouts-1552257301715.html

Alexander, Sneha and Vishnu Padmanabhan, Vishnu (2019c, 26 March). With Ujjwala, more LPG access but limited usage.Live Mint.

Retrieved on 23 June from, https://www.livemint.com/news/india/withujjwala-more-lpg-access-but-limited-usage1553571493940.html

Bhattacharyya, Rituparna (2014). Good Governance and Development Mandate. Journal Space and Culture, India, 2(1), 1-4. https://doi.org/10.20896/saci.v2i1.65

Bhattacharyya, Rituparna (2015a). Understanding the Spatialities of Sexual Assault against Indian Women in India, Journal Gender, Place and Culture,22(9), 1340-1356, DOI:

10.1080/0966369X.2014.969684

Bhattacharyya, Rituparna (2015b). Working Childhoods: Youth, Agency and the Environment in India. Progress in Development Studies, 15(3), 292-294, DOI: $10.1177 / 1464993415578570$
Bhattacharyya, Rituparna (2016). Street Violence against Indian Women in India: Mapping Prevention Strategies, Asian Social Work and Policy Review, 10 (3), 311-325, DOI: 10.1111/aswp.12099

Bhattacharyya, Rituparna (2017). India Rising. Journal Space and Culture, India, 5(1), 1-11. https://doi.org/10.20896/saci.v5i1.258

Borah, Poonam (2018). Engaging with the Law: Decriminalisation of Homosexuality and the Johar Judgement, 2018. Journal Space and Culture, India, 6(3), 5-22.

https://doi.org/10.20896/saci.v6i3.400

Bremmer, Ian (2019, 09 May). Modi Is India's Best Hope for Economic Reform. Time.

Retrieved on 03 June 2019 from, https://time.com/5586417/hope-for-economicreform-in-india/

Census of India. 2011: CensusInfo India. Retrieved on 20 December 2014 from, http://www.devinfolive.info/censusinfodashbo ard/

Choudhary, Sanjeev (2018, 04 December). A Record Leap: LPG Cylinder now used by $89 \%$ Households in India. The Economic Times.

Retrieved on 20 January 2019 from, https://economictimes.indiatimes.com/industry /energy/oil-gas/lpg-cylinder-now-used-by-89households/articleshow/66930092.cms

Das, Madhuparna (2019, 17 May). BJP a goonda party, EC is Modi-Shah brother: Mamata Banerjee, The Economic Times. Retrieved on 30 May 2019 from, https://economictimes.indiatimes.com/news/el ections/lok-sabha/west-bengal/bjp-a-goondaparty-ec-is-modi-shah-brother-mamatabanerjee/articleshow/69367319.cms

Daman, Sunil (2019, 23 February). UPA or NDA: Which is Better? Factual Comparison. Hindu. Retrieved 23 April 2019 from, https://www.patheos.com/blogs/hindu2/2019/ 02/upa-or-nda-which-is-better-factualcomparison/

Dixit, Ayush Mohan (2019, After 600 artistes appeal vote against BJP, 907 artistes and persons in literature urge to vote for the party, 
Zoom. Retrieved on 06 June 2019 from, https://www.timesnownews.com/entertainme nt/news/people/article/after-600-artistesappeal-vote-against-bjp-907-artistes-andpersons-in-literature-urge-to-vote-for-theparty/397772Kakoti

Election Commission of India. Retrieved on 21 June 2019 from, https://eci.gov.in/

Frøystad K (2018) Failing the third toilet test: Reflections on fieldwork, gender and Indian loos. Ethnography, 1-19, DOI:

$10.1177 / 1466138118804262$

Gramsci, Antonio (1999). Selection from the Prison Notebooks. ElecBook: London. Retrieved 20 January 2019from, http://abahlali.org/files/gramsci.pdf

Lakshmi R (2015,0 4 June). India is building millions of toilets, but that's the easy part. The Washington Post. Retrieved on 20 November 2018 from, https://www.washingtonpost.com/world/asia_ pacific/india-is-building-millions-of-toilets-buttoilet-training-could-be-a-bigger-

task/2015/06/03/09d1aa9e-095a-11e5-a7adb430fc1d3f5c_story.html?utm_term $=.0 \mathrm{~d} 601 \mathrm{ee}$ $\operatorname{bad} 25$

Sabnavis, Madan (2019, 28 April). NDA vs UPA: The economic scorecard. The Hindu Business Line. Retrieved on 26 May 2019 from, https://www.thehindubusinessline.com/opinio $\mathrm{n} /$ columns/nda-vs-upa-the-economicscorecard/article26973332.ece

Mahanta, Ratul (2016). GST in India:

Expectations and challenges. Journal Space and Culture, India, 4(2), 3-8.

https://doi.org/10.20896/saci.v4i2.215

Nathoo L (2015, 21 August) India's trouble with toilets: Government sanitation drives fail to sway those who believe going outdoors is more wholesome. Independent. Retrieved on 20 November 2018 from, https://www.independent.co.uk/news/world/a sia/india-rejects-the-toilet-how-governmentsanitation-drives-have-failed-to-sway-thosewho-believe-10466041.html
Padmanabhan, Vishnu (2019, 21 April). Has

Aadhaar improved welfare delivery? Live Mint.

Retrieved on 20 June 2019 from, https://www.livemint.com/news/india/hasaadhaar-improved-welfare-delivery1555861461316.html

Pulla, Venkat (2016). Unprecedented Move. Journal Space and Culture, India, 4(2), 1-2. https://doi.org/10.20896/saci.v4i2.221

Pulla, Venkat (2017). Gramscian 'Counter hegemony' in Narendra Modi's New India Perspective. Journal Space and Culture, India, 4(3), 1-6. https://doi.org/10.20896/saci.v4i3.247

Rajagopal, Krishnadas (2018, 07 September). SC decriminalises homosexuality. The Hindu.

Retrieved on 22 June 2019 from, https://www.thehindu.com/todays-paper/scdecriminalises-

homosexuality/article24887363.ece

Ramani SV (2016, 19 November) Why It's Easier for India to Get to Mars than to Tackle Its Toilet Challenge, Development \& Society: Waste, Water, Human Security, Sanitation. Retrieved on 20 November 2018 from, https://ourworld.unu.edu/en/why-its-easierfor-india-to-get-to-mars-than-to-tackle-itstoilet-challenge

Sabnavis, Madan (2019, 28 April). NDA vs UPA: The economic scorecard. The Hindu Business Line. Retrieved on 26 May 2019 from, https://www.thehindubusinessline.com/opinio $\mathrm{n} /$ columns/nda-vs-upa-the-economicscorecard/article26973332.ece

Sen, Amartya (2019, 24 May).Modi Won Power, Not the Battle of Ideas, The New York Times.

Retrieved 26 May 2019

from,https://www.nytimes.com/2019/05/24/o pinion/india-modi-election.html

Sharma, Daamini (2019, 10 April). After 700 Artists' Anti-Modi Election Appeal, 907 Other Artists Begin Counter-campaign Seeking 'continuance Of PM Modi-led Government'. Full List Here, Republic. Retrieved on 01 May 2019 from, https://www.republicworld.com/election- 
news/indian-general-elections/after-700artists-anti-modi-election-appeal-907-otherartists-begin-counter-campaign-seekingcontinuance-of-pm-modi-led-government-fulllist-here

Singh, Suman (2016). The Maternity Benefit (Amendment) Bill, 2016: A Critical Analysis. Journal Space and Culture, India, 4(2), 22-28. https://doi.org/10.20896/saci.v4i2.210

Singh, Suman (2018). Self-Proclaimed God Convicted, POCSO Amended. Journal Space and Culture, India, 6(1), 7-15.

https://doi.org/10.20896/saci.v6i1.319

Singh, Tavleen (2019, 26 May). No revival of that old order: The idea of India in which there are privileges and not rights is dead. The Indian Express. Retrieved on 28 May 2019 from, https://indianexpress.com/article/opinion/colu mns/election-results-modi-rahul-gandhicongress-english-elitism-colonialism-no-revivalof-that-old-order-5748464/

Singareddy, R., Ranjan, P., Annamalai, B., \& Chandrasekaran, S. (2019). Financial Inclusion
Remodeling: Including the Excluded Masses. Journal Space and Culture, India, 6(5), 178-188. https://doi.org/10.20896/saci.v6i5.375

Sridhar, Naga, G. (2019, 19 February). PM Jan Dhan Yojana accounts see record $24 \%$ rise in average balance, The Hindu Business Line. Retrieved on 21 June 2019 from, https://www.thehindubusinessline.com/money -and-banking/pm-jan-dhan-yojana-accountssee-record-24-rise-in-averagebalance/article26313715.ece

Sur, Esita (2018). Triple Talaq Bill in India: Muslim Women as Political Subjects or Victims?. Journal Space and Culture, India, 5(3), 5-12. https://doi.org/10.20896/saci.v5i3.299

Taseer, Aatish (2019, 09 May). Can the World's Largest Democracy Endure Another Five Years of a Modi Government?Time. Retrieved on 03 June 2019

from,http://time.com/5586415/india-electionnarendra-modi-2019/ 